\title{
Initiation of a "lost" large river on the East Asia margin in the Middle Eocene
}

Xiaowei $\mathrm{Fu}^{1}$, Rong Yang ${ }^{2 *}$, Weilin $\mathrm{Zhu}^{{ }^{*}}$, Shouye Yang ${ }^{1}$, Jianhua Geng ${ }^{1}$, Luyao Zhang ${ }^{1}$

${ }^{1}$ State Key Laboratory of Marine Geology, Tongji University, Shanghai, China

${ }^{2}$ School of Earth Sciences, Zhejiang University, 310027 Hangzhou, China

${ }^{*}$ Corresponding author

Rong Yang: royang1985@zju.edu.cn

Weilin Zhu: zhuwl@tongji.edu.cn

Mailing addresses of other authors:

Xiaowei Fu : fu_xiaowei@tongji.edu.cn

Shouye Yang: syyang@tongji.edu.cn

Jianhua Geng: jhgeng@tongji.edu.cn

Luyao Zhang : zlygreat0@163.com

\begin{abstract}
The forming of large rivers are the integral consequences of the deep earth process and the surface. In contrast to the hot topics for rivers related to orogenic domains, riftrelated large rivers are largely ignored especially in deep time studies. The Cenozoic East Asia margin provides very good opportunity to observe this kind of rivers. It has been believed that basin-and-swell physiography dominated the East Asia margin and impeded the forming of large rives in the early Cenozoic. In this paper, we combined provenance analysis of East China Sea Basin, where is a crucial place to trace the river evolution in East Asia margin, and regional geologic constraints to reveal drainage
\end{abstract}


reorganizations. Detrital zircon $\mathrm{U}-\mathrm{Pb}$ ages from the Early Eocene sediments of the East China Sea Basin are firstly reported. Our results together with literature data demonstrate that regional provenance changes occurred at the middle Eocene from one singe age peak at $\sim 110 \mathrm{Ma}$ of proximal sources to multiple age spectrum derived from far inland. Source to sink analysis indicated that the North China Block and Korea Peninsular provided the most detritus. Sedimentation and tectonic features of rift basins in the potential source areas indicated that rivers flowed into Bohai Basin and Jianghan Basin cannot provide terrigenous clasts for the lower reaches in the Eocene. Contrastingly, the dominantly fluvial sediments across the Subei-South Yellow Sea Basin suggested external river system and a bypassing region since the middle Eocene, coinciding with provenance change in ECSB. All these demonstrated that a large river (East Asia River) established in east Asia margin in the middle Eocene and flowed southwestward approximately $1500 \mathrm{~km}$ to the sea in southern ECSB. This river might last to the middle Miocene. The deep earth processes driven by Izanagi-Pacific ridge subduction resulted in the overfilled stage of Subei-South Yellow Sea Basin and the post-rift subsidence in west depression of ECSB, and thus facilitated the initiation of the EAR. Our finding shed new light on the evolving landscape in East Asia and showed how subduction of deep earth process controlled the initiation of rift-related large rivers.

\section{Introduction}

The formation of a large river systems is the coupling between deep earth process and the surface process (Brookfield, 1998). The evolving of gigantic rift systems can establish large rivers and manifest striking landscape that contrasts to the rivers associated with orogenic domains (Paul, 2021), e.g. the present-day East Africa rifts (Frostick and Reid, 1989; Paul et al., 2014). However, this kind of large river systems are rarely reported in the rift systems of geological time. The East Asia margin was 
characterized by numerous rift basins that extended from Bohai Basin to the South China Sea region with a range of thousands of kilometers for the most time of the Cenozoic (Ren et al., 2002; Xu et al., 2014b), which provide a very good opportunity to reveal large river systems associated with the evolving rift basins.

Furthermore, the resulting large river systems of the Cenozoic rifts in East Asia margin facilitate the understanding of the evolution of river networks in East Asia. It is widely known that large drainage basins of East Asia have formed in the Cenozoic in response to the uplift of the Tibetan Plateau and the subsidence of the rift basins in the East Asia coupled by climate changes (Brookfield, 1998; Clark et al., 2004; Wang, 2004; Zheng et al., 2013; Zheng, 2015). Numerous efforts were devoted to manifest the histories of the present-day continental river systems that radiating from the Tibetan Plateau (Deng et al., 2017; He et al., 2020; Liu et al., 2017; Richardson et al., 2010; Zhang et al., 2021b; Zheng et al., 2020; Zheng et al., 2013). However, drainage basins before the presentday are still poorly known (Fig.1). Contrasting to the current landscape, the resulting drainage patterns during the persuasive-rift-basins evolving are largely overlooked. A traditional view was that "basin-and-swell" physiography might be the main feature in the early Cenozoic in East Asia (Wang, 2004). In this context, there might be no large river system before the present-day river system because the widely distributed rift basins and swells have impeded the formation of large river systems (Wang, 2004). Recently, provenance analysis of East Asia margin suggested the possibility of a large river system. The predominately late Mesozoic magmatic rocks of proximal source areas dominated the provenance of Palaeocene sediments in the southern East China Sea Basin (ECSB) (Fu et al., 2015a; Chen, 2015). While, multiple peaks with extraordinarily old zircon ages (>1800 Ma) were widely found in the Eocene-mid Miocene sediments in the ECSB (Wang et al., 2018b; Zhang et al., 2018; Fu et al., 2020). One view thinks that main source areas located in the adjacent uplifts such as Hupijiao Uplift and Haijiao Uplift (Zhang et al., 2018). While, increasing evidence manifested that distant inland of Yangtze Block and North China Block were the main source areas (Fu et al., 2021; Wang et al., 2018). Some studies proposed that this provenance transition from adjacent uplifts to far inland occurred in the Oligocene sediments in the 
ECSB and was related to the reorganization of the present-day Yangtze River (Wang et al., 2018; Zhang et al., 2021a). But much larger number of samples that covering most of the Cenozoic sediments manifested that this transition can be traced at least in the middle Eocene (Fu et al., 2021) which time the Yangtze River cannot be established (Zhang et al., 2021b; Zheng et al., 2013; Zheng, 2015). In this context, this large river should not be the Yangtze River. Thus, the time when this river was initially formed and the place where the extent of the catchment area was are still in hot debate.

Still, how this large river system initially formed is also poorly known. Although the North China Block and Korea Peninsular were proposed as the main source regions (Fu et al., 2021; Kwon and Boggs, 2002), but the details that how the detritus was delivered through rift basins to the southern ECSB over one thousand kilometre are far from known. Furthermore, the effects of the evolving rift basins were largely ignored in the previous studies (Fu et al., 2021; Wang et al., 2018; Zhang et al., 2021a), even these basins were widely distributed in the potential catchment of this river and have different evolutionary histories (Ren et al., 2002; Xu et al., 2021) that might facilitate or impede the forming of a large river system.

Multiple provenance methods are widely used for tracing the evolving of the river system of the present and historical period intrinsically by the comparing between potential source areas and the sediments. However, besides the uncertainties caused by fertile of minerals in different lithology, weathering, transporting and diagenesis (Caracciolo, 2020; Chew et al., 2020; Eynatten and Dunk1, 2012), tracing a paleodrainage system also challenged by significant variations along the length of the rivers, which primary caused by the input of tributaries with diverse lithologic and aging features (Cawood et al., 2003; Hietpas et al., 2011). In this study, we combined the detrital zircon ages and regional geology to limit the uncertainties of provenance analysis and fully reveal a paleodrainage system that has existed in the East Asia. We report detrital zircon ages from the late Palaeocene to early Eocene sediments and together with previous works to present a complete provenance evolutionary history for ECSB for the first time. And thus, the initial provenance change that caused by regional organization of drainage patterns were observed. Furthermore, the sedimentation and 
major tectonic features of rift basins in the potential areas before and after the provenance shift were used to constrain the extent of this river system. By consider the plate tectonics that controlled the evolving of reginal rift basins, the deep earth processes were used to explain the forming of this large river system.

\section{Geological background}

\subsection{East China Sea Shelf Basin}

The East Asia margin experienced intense extension since the late Mesozoic and resulted in large number of rift basins (Fig.1). The evolutionary histories of these basins showed temporal and spatial variation. The Jianghan Basin (Zheng et al., 2011), SubeiSouth Yellow Sea Basin (Xu et al., 2021), East China Sea Basin (Zhu et al., 2019) began to rift in the late Cretaceous. Initial rifting of the Northern Yellow Sea Basin occurred at middle Jurassic (Wang et al., 2020). The rifting in Bohai Basin was initiated in the early Cenozoic (Qi and Yang, 2010). All these basins have many subsidence centres and suggested basin-and-swell physiography (Wang, 2004). The accommodation that caused by intense activity of boundary faults outpace the deposition rate in the rifting stage. Thus, widespread lacustrine successions that characterized by various proportions of oil shale, black mudstone and evaporate were known for most of these basins (Huang et al., 2015; Song et al., 2020; Zheng et al., 2011). But for the southern ECSB, the lacustrine environment in early rifting stage replaced by shallow marine setting in the later stage (Zhu et al., 2019). The time that entered post-rift phase was the beginning of Neogene for Jianghan Basin (Wu et al., 2017), Bohai Basin(Qi and Yang, 2010) and Subei-South Yellow Sea Basin (Xu et al., 2021). The termination of rifting 
accompanied by transient basin-wide erosion, but this erosion lasted for much longer time in the Subei-South Yellow Sea Basin than others from late Eocene to the end of the Oligocene (Xu et al., 2021).

Among these basins, the ECSB is the largest in China and has been believed that it was the most possibly place that large river systems flowed in (Deng et al., 2017; Fu et al., 2021). The formation of the ECSB has been discussed for decades (Ren et al., 2002; Xu et al., 2014a). Recently, Zhu et al. (2019) proposed that the subsequent subduction of the Izanagi Plate and Pacific Plate resulted in the rifting of the western depression zone (initiated at $\sim 72 \mathrm{Ma}$ ) and eastern depression zone (initiated at $50 \mathrm{Ma}$ ), respectively. Based on the comprehensive tectonic-sedimentary evolution of all the sags, they also provide a regional sedimentary-palaeogeographic evolution model of the whole basin from the early Palaeocene to the Oligocene. In their model, Palaeocene sediments were mainly isolated in rifts by boundary faults. The post-rift sediments of the western depression zone covered the inner uplift in the rifts since the Eocene. From the late Eocene to Oligocene, the western depression zone experienced widespread erosion, and the extension centre migrated to the eastern depression zone. The thick fluvial deposits in the northern part of the eastern depression zone (Kwon and Boggs, 2002) and the marine-influenced or thinner sandstone beds towards the south (Zhang et al., 2018). During the early-middle Miocene, the whole ECSB exhibited regional subsidence, and sediments covered all of the former uplifts in the ECSB (Lee et al., 2006; Zhu et al., 2019). In contrast to the highly marine-influenced southern part of the ECSB, the northern part was mainly palustrine to fluvial quartzose sandstone interbedded with 
greenish claystone and coals (Lee et al., 2006). In the late Miocene, marine conditions started to significantly influence the northern ECSB (Lee et al., 2006).

\subsection{Defining potential sources}

Previous studies have suggested that geographically adjacent neighbours of ECSB, including the North China Block, Yangtze Block, Cathaysia Block, Korean Peninsula and Okinawa Trough located SW of Japan, could be potential source regions for the sediments deposited in these basins (Deng et al., 2017; Fu et al., 2021) (Fig. 1). The production of certain zircons mostly depends on the exposed area, weathering rate and zircon fertility (Fedo et al., 2003). Transport, sedimentary factors and even sampling and mineral separation can also affect the zircon age spectra (Cawood et al., 2003; Sláma and Košler, 2012). The zircon age features of the bedrock in these potential source areas are difficult to precisely determine, especially over geological time. Thus, an effective and popular method is using detrital zircon age pattern of modern rivers that covering most part of the potential source areas to represent the provenance features of these source areas, especially the palaeodrainage studies in East Asia (Deng et al., 2017; He et al., 2020; Shao et al., 2017).

The Korean Peninsula consists of five tectono-structural units/terranes (Metcalfe, 2006). The Nangrim massif and Pyeongnam basin belongs to the North China Block, the Gyeonggi Massif, Okcheon Belt and Yeongnam Massif make up the southern part of the Korean Peninsula. Rivers covering most part of the Korean Peninsula all exhibit prominent populations with an age of $\sim 1850 \mathrm{Ma}$ and a minor population of $\sim 220 \mathrm{Ma}$ (Fig.2). For the south Korea, a small number of Jurassic ages peak at 190 Ma also can be observed (Choi et al., 2016; Wu et al., 2007). These features well agree with crustal evolution of this region (Choi et al., 2016; Wu et al., 2007).

The Qinling-Dabie-Sulu Orogen lies between the Yangtze Block and NCC (Fig.1). Although this orogenic belt mainly resulted from the collision of the two blocks, multistage arc-continent and continent-continent collisions occurred (Wu and Zheng, 2013). The ultrahigh-pressure and high-pressure metamorphic rocks, Mesozoic granite, 
crystalline basement rocks of the SCB, NCC and North Qinling Terrane are all exposed, and thus, the zircon ages of these rocks are complex from $\sim 2.9$ Ga to the Cretaceous (Li et al., 2017; Wu and Zheng, 2013). Despite of these variations, zircons with ages ranging from 254-205 Ma document continental collision between the Yangtze Block and NCC in the Dabie-Sulu orogenic belt (Wu and Zheng, 2013; and references therein), consistent with the context of pervasive exposure (Li et al., 2017; Wu and Zheng, 2013). The South China Block was formed by the amalgamation of the Yangtze Block and the Cathaysia Block at $\sim 970-820 \mathrm{Ma}$, although the history of aggregation of the fragmented blocks forming the two major blocks is much more complicated (Yao et al., 2019).

The Yangtze Block experienced multiple crustal growth events, such as those at $~ 3200$ $3300 \mathrm{Ma}, \sim 2900 \mathrm{Ma}, \sim 2400-2700 \mathrm{Ma}$, and 800-740 Ma (Chen et al., 2013; Wang et al., 2010), but the crystalline basement is scarcely exposed (He et al., 2014). The limited exposure is consistent with the low proportion of old zircons $(>1000 \mathrm{Ma})$ in the branches of the middle and lower reaches of the Yangtze River (He et al., 2014) (Fig. 2).

The Cathaysia Block shares most of the Precambrian generation and reworking characteristics with the Yangtze Block (Li et al., 2014b). Beyond that, late Mesozoic magmatic and sedimentary rocks are also widely spread in the Cathaysia Block. However, rivers sourced from the Cathaysia Block are predominately fed by Mesozoic ages (Xu et al., 2007; Xu et al., 2016; Zhang et al., 2015) (Fig. 2). This may be caused by the widespread late Mesozoic magmatic rocks and limited exposure of the old crystal basement rocks (Fu et al., 2015a; Xu et al., 2016) across the eastern Cathaysia Block, which resulted in the late Mesozoic zircons being the most abundant proportion in the rivers in this region, except the Min River which exhibits an obvious peak at $\sim 420 \mathrm{Ma}$ consistent with old strata that mainly distributed inland (Xu et al., 2016). 


\section{Samples and methods}

Previous studies have reported a great number of detrital zircon data from the ECSB (Fu et al., 2021) and shown a complex age spectra in the middle Eocene and nearly single peak of the late Mesozoic age in the Paleocene, however, the absent of sample form the early Eocene sediments make the uncertainty of when the complex age spectra firstly appeared. To determine the first appearance of the provenance changes, we selected three sample from Well W1, J1 and L1, respectively (Fig.1B). In these wells, Fu et al. (2021) have observed complex age spectra in the middle Eocene. Furthermore, two samples from late Paleocene sediments of W1 and L1 to confirm the probably changes. The stratigraphic ages of these samples were followed Fu et al. (2021). $\mathrm{U}-\mathrm{Pb}$ dating was conducted by laser ablation-inductively coupled plasma-mass spectroscopy (LA-ICP-MS) in State Key Laboratory of Marine Geology, Tongji University. The instrumentation comprises an Agilent 7900 ICP-MS coupled with a 193 excimer laser (Resolution M50). Cathodoluminescence images together with transmission light images were used to avoid inclusions and locate analytical spots $(26 \mu \mathrm{m})$. Software ICPMSDataCal (Liu et al., 2009) was applied to process the Raw data. Approximately 120 grains were randomly selected for dating (Vermeesch, 2004). Zircon grains with ages $<10 \%$ discordance were selected as the valid ages. These valid ages younger than and older than $1,000 \mathrm{Ma}$ were adopted the ${ }^{206} \mathrm{~Pb} /{ }^{238} \mathrm{U}$ ages and ${ }^{207} \mathrm{~Pb} /{ }^{206} \mathrm{~Pb}$ ages, respectively (Griffin et al., 2004). U-Pb age distributions of kernel density estimation $(\mathrm{KDE})$ spectra (bin=20) were made using the provenance package in R (Vermeesch et al., 2016).

\section{Results}

The detrital zircon $\mathrm{U}-\mathrm{Pb}$ age results from all the samples are given in Supplementary material. The age data of all the five samples in this study are shown in the KED plots in Fig. 3 together with other previous data from the ECSB that obtained from the Upper 
and lower strata for comparing. Thus, all the Cenozoic strata in the ECSB can be revealed in this study. All the three sample from early Eocene sediments show nearly identical age spectra with one single age peak at $\sim 110 \mathrm{Ma}$ and almost absence of other ages. The same features are also observed in the other two samples from the Paleocene (borehole $\mathrm{W} 1$ and $\mathrm{L} 1$ ) and the Paleocene sediments that previous reported in this region (Fig.3). While strikingly different age spectra with multiple age peaks at $\sim 110 \mathrm{Ma}, 220$ Ma, $800 \mathrm{Ma}, 1850 \mathrm{Ma}$ and $2500 \mathrm{Ma}$ initially appeared in the middle Eocene.

\section{5 discussion}

\subsection{Provenance interpretation}

Our Paleocene samples with single age peak at $\sim 110$ Ma are consistent with detrital zircon feature of the Paleocene sediments that previously reported, which sourced from the local source area in the west (Fu et al., 2015a; Fu et al., 2015b; Chen et al., 2017a; Chen et al., 2017b). The early Eocene samples, first reported in this study, also maintaining the identical provenance feature suggesting that the sediments were also derived from the same local sources. In order to observed the relative dissimilarities between multiple samples and the potential source areas, multidimensional scaling (MDS; Vermeesch et al., 2016) that based on Kolmogorov-Smirnov test is also applied (Fig.4). The Paleocene and Early Eocene samples fall in the same cluster, but far from the adjacent Ou River (Fig.4) although this river also shows similar age spectrum (Fig.3). The spectrum of Ou River with a prominent peak at $\sim 133 \mathrm{Ma}$ is slightly older than the zircon ages ( $110 \mathrm{Ma})$ of the Palaeocene-early Eocene sediments in the LishuiJiaojiang Sag. Thus, the local western rivers were not simply derived from the Ou River. We infer that these transverse rivers mainly drained the Zhemin Uplift, consistent with the trenchward younging of Cretaceous magmatic rocks (Li et al., 2014a) and the proximal drainage patterns of the rift basin (Gawthorpe and Leeder, 2008). 
In contrast to the proximal source characterized by the prominent single peak at $\sim 110$ $\mathrm{Ma}$, the provenance of complex age distribution initially appeared in the middle Eocene. $\mathrm{Fu}$ et al. (2021) observed that this provenance feature lasted to the middle Miocene and suggested that these sediments were mainly derived from North China and South Korea. Similar provenance characteristics were also reported by Zhang et al. (2018) and Wang et al. (2018) from the Oligocene sediments in Xihu Sag. Zhang et al. (2018) claimed that these Oligocene sediments with the same provenance features were mainly derived from the local uplifts around the Xihu Sag, especially the Precambrian ages, which were sourced from the Hupijiao Uplift to the northeast of the Xihu Sag. Because all of the local uplifts in the ECSB were no longer as the source region, as revealed from the overlapping Miocene strata (Lee et al., 2006; Zhu et al., 2019), the consistent provenance features of the early-middle Miocene sediment (Fig. 3) indicated that the main provenance was somewhere outside the ECSB. From the middle Eocene to the middle Miocene, all the samples fall in the same cluster in MDS plot and clearly show close affinity with the North China and South Korea.

The prominent and stable age group centred at $\sim 225$ Ma indicates that the Sulu-Dabie Orogeny contributed a great deal of material. The weak peak at $\sim 800$ Ma shows that the Yangtze Block also supplied material (Clift et al., 2013), although a quite limited amount. This age population is widely observed in samples from the SYSB (Fu et al., 2021; Zhu et al., 2020) and is consistent with the Neoproterozoic Jiangnan Orogen, which resulted from the collision between the Yangtze Block and the Cathaysia Block (Yao et al., 2019).

Furthermore, the proportions for source samples can be calculated by inverse Monte Carlo modelling (Sundell and Saylor, 2017), which provide the possibility to determine the quantitative contributions of different sources based on detrital zircon age distributions. Considering the division of wide spread sea water in the southern ECSB, 
the source samples of Min River and Jiulong River are not used in modelling. Our results are consistent with the MDS (Fig.4) and suggest that the most contributions of sediments were from NCB (34\%) and Korean Peninsula (34\%). The contribution of paleo-Yangtze River is 15\%, Qiantang River is $10 \%$ and Ou River is 7\% (Fig. 4B).

Thus, we suggest that a sharp provenance change occurred in the middle Eocene in ECSB. Thereafter, the ECSB probably dominated by one river system, which likely originated far inland, till the middle Miocene.

\subsection{Sedimentation of rift Basins in the potential source regions and constrains on a drainage basin}

Although source-sink comparison suggested that the source regions of the middle Eocene ECSB began to extend to North China and South Korea, the range of the source areas and transport routes of the detrital material need further constraints. According to the existing regional geological understanding, there are several Cenozoic rift basins in the potential source areas (Ren et al., 2002), including the Bohai Basin, North Yellow Sea Basin (NYSB), Subei-South Yellow Sea Basin (SYSB), Jianghan Basin and ECSB. Noteworthy, the Cenozoic provenance in SYSB was characterized by changing provenance features both in time and space, suggesting multiple sources that fed this basin (Fu et al., 2021; Zhu et al., 2020). This might result from the input of wandering branches. By contrast, the ECSB showed stable and sustaining detrital zircon age spectrum from the Middle Eocene to Middle Miocene (Fig.3), possible reflecting compositionally stable mixture for the downstream (Caracciolo, 2020). Therefore, it is hard to compare sediments in ECSB with sediments in its potential upper reaches, regionally geological constraints are essentially required to reveal a river system resulting in provenance change occurred at the middle Eocene.

The sedimentary facies in rift basins can provide crucial information on the dispersion patterns of detrital sediments eroded from uplifted areas and other source regions. A lake would trap all the terrigenous sediments that delivered in the lake from its drainage 
basins even for an open lake system (Einsele and Hinderer, 1997). Thus, if a rift basin developed relatively stable lacustrine conditions, especially semi-deep to deep water, the basin would be a sedimentary-isolated basin. The existence of the lake can be inferred from the existence of lacustrine sediments, such as semi-deep to deep lacustrine-facies mudstone or oil shale (Bohacs et al., 2000). In contrast, if a rift basin is dominated by fluvial sediments without the lacustrine deposition or evaporite rocks, the basin would allow the terrigenous sediments to be delivered to the lower reaches of the river system rather than trap them.

When the provenance change occurred in the middle Eocene, the Bohai Basin was at a synrift stage and featured by a series of grabens and half garbens (Allen et al., 1997). The wide spread oil shale, evaporate, semi-deep lake mudstone, carbonates and turbidites in most of these sub-basins indicate stable lake environment, even hydrologyisolated lakes (Feng et al., 2013; Huang et al., 2015; Wang et al., 2015; Ma et al., 2017) (Fig.5). That means the Bohai Basin had trapped all the detritus that derived from its drainage basins. Similarly, the Jianghan Basin was also a hydrology-isolated basin that characterized by oil shale and evaporites (Zheng et al., 2011) (Fig.5).

In the North Yellow Sea Basin, basin-wide truncations in seismic sections showed angular unconformities implying intense erosion from the late Cretaceous to the Eocene (Liu et al., 2015; Wang et al., 2017). The erosion indicated that the North Yellow Sea Basin region would supply detrital material to the other depositional districts.

In the Subei-South Yellow Sea Basin, Sanduo Formation is middle Eocene in age and that the late Eocene-Oligocene layer is absent (Zhang et al., 1992; Cai et al., 1992; Shu et al., 2005) (Fig. 5). Since the middle Eocene, profound changes of sedimentary environment occurred in this region. The early Eocene lake environment (Dong, 1999; Liu et al., 2014) was terminated and replaced by overwhelmingly fluvial environment. The lithology of the Sanduo Formation varies significantly. In the Subei Basin, the lithology is mainly oxidized mudstone, sandstone, and conglomerate, interbedded with grey or greyish-green mudstone (Bureau of geology and mineral resources of Jiangsu Province, 1984; Cai et al., 1992), indicating a dominantly fluvial environment. The 
counterpart in the northern SYSB is dominated by red sandstone and mudstone, also implying fluvial facies (Yi et al., 2003). This scenario means that the SYSB basins was an over-filled basin in the middle Eocene (Gawthorpe and Leeder, 2008). And thus, the drainage networks flowed in this region would continue to flow downstream led to the SYSB basins became bypassing region (Fig.5).

Most of Korea might have provided material to the ECSB. Korea was proximity to the SYSB and experienced erosion during the Cenozoic. It is mainly covered by preCenozoic rocks and does not contain any large Cenozoic basins; only Neogene basins are associated with the evolution of the Japan Sea (Yoon and Chough, 1995) and are distributed along the eastern margin of the Korean Peninsula (Chough et al., 2000). This means that most of the Korean Peninsula was an erosional region in the Cenozoic. It has been suggested that regional uplift by thermal doming was widely distributed before rifting and spreading of the Japan Sea (Kano et al., 2007). This facilitated the development of principally south-westward river networks. Furthermore, before the opening of the Japan Sea, SW Japan was connected with Korea (Fig. 6) (Van Horne et al., 2017), implying that part of this region could also have been a provenance area.

As discussed above, the BoHai Basin and Jianghan Baisn were sedimentary-isolated basins or even hydrology-isolated basins and cannot be the source areas of the ECSB in the middle Eocene (Fig.6A). Considering the middle Eocene appearance of NCCKorean zircon age spectra in the ECSB, the widespread erosion in the North Yellow Sea Basin and bypassing region of the Subei-SYSB basins indicate that these basins and the related drainage basins could be the source areas of the ECSB.

Thus, we propose that there was a large river system that first established in the middle Eocene and flowed $\sim 1500 \mathrm{~km}$ southwestward along the present-day east China margin. This drainage basin extends to most of Korea, part of the Sulu-Dabie Orogenic Zone and the middle-lower reaches of the present Yangtze River (Fig. 6B). Notably, this river 
flowed along the west Depression of the ECSB. Here, we named the tributary that originated in Korea and flowed through the SYSB the "Sino-Korea River" and the branch located in the present middle-lower Yangtze River as the "palaeo-Yangtze River" to distinguish it from the present Yangtze River. We refer the mainstream that flowed through the ECSB as the "East Asia River" (EAR). The Bohai Basin and Jianghan Basin were isolated basins. Thus, we infer that there were watersheds between EAR and the two basins. However, the watersheds cannot be precisely identified based on the present data.

\subsection{Formation of the EAR and its profound implications}

When the EAR initially formed at middle Eocene ( $\sim 8 \mathrm{Ma}$ ), profound tectonic events occurred in East Asia. Along East Asia margin, the trench-subparallel subduction of the Pacific-Izanagi ridge (56-46 Ma) led to the subduction of Izanagi Plate replaced by Pacific Plate, although the extent of this ridge was arguable (Faccenna et al., 2012; Müller et al., 2008; Seton et al., 2015; Wu and Wu, 2019). The young Pacific Plate subduction coinciding with reorganization of Pacific plate caused weaker mantle convection and thus resulted in widespread erosion across SYSB (Xu et al., 2021). After this tectonic event, the middle Eocene SYSB became an overfilled basin as discussed above. The widespread erosion and subsequent-overfilled Subei-SYSB basin facilitate the forming of external river system because the detritus derived from source areas had to be delivered outside this basin. As this external river formed, the ECSB was the most likely place in which this river flowed since a much lower altitude in the southern ECSB which confirmed by marine setting (Fig. 6). Additionally, the southwest Japan was connected with Korean Peninsula (Van Horne et al., 2017), which blocked the eastward path of EAR. This inference was consistent with the NCC and Korean Peninsula features of the provenance in the southern ECSB.

Interestingly, the EAR flowed along the East Asia margin south-westward instead of simply draining eastward as present. There are two tectonic zones that may have facilitated the southward flow of the EAR. First, axial rivers usually form in the post- 
rift phase of rifts. During this stage, the activity of boundary faults weakens, and general subsidence predominates, resulting in continuous lowlands along the rift axis and thus facilitates the forming of axial rivers (Frostick and Reid, 1989). The Benue River in West Africa is a good case; it flows along the Benue Trough (once a rift basin) for 1200 km (Frostick and Reid, 1989). Since the Eocene, the termination of rifting in the western depression zone of ECSB has been accompanied by regional subsidence (Zhu et al., 2019). The topographical highs between subbasins diminished, as revealed by the sediment-covered uplifts (Zhu et al., 2019). Interestingly, both shoulders can continue to maintain relatively high topographical expressions in the post-rift stage (Frostick and Reid, 1989). This process helped to form negative relief along the length of the West Depression of ECSB.

Second, rifting is accompanied by distinct flank uplift (Chéry et al., 1992; Weissel and Karner, 1989). The onset subduction of Pacific Plate caused the eastward migration of extension and thus resulted in the rifting of east depression in ECSB (Zhu et al., 2019). This process would further keep high topographical expressions along the east shoulder of the West Depression (Fig.6B), which was confirmed by seismic sections across the ECSB (Zhu et al., 2019). The EAR initially formed in the middle Eocene and arrived at southern ECSB (Fig. 6). This time is slightly later than the beginning of the post-rift stage (early Eocene) (Zhu et al., 2019) and the formation of a continuous low rift valley in the western ECSB, but is coincident with the external rivers in the SYSB.

The continuous and stable provenance features of EAR lasted to the end of the middle Miocene (Fig.3) until the present-day Yangtze River started to control the East Asia margin since the late Miocene (Fu et al., 2021; Sun et al., 2021; Zhang et al., 2021b). During the late Eocene to Oligocene, the EAR might flowed into the east depression zone since this region was the subsidence center of the ECSB and the west depression zone uplifted and eroded (Zhu et al., 2019).

The mid-Eocene appearance of the EAR that firstly revealed in this paper shed new light on the landscape evolution of the East Asia. Before the present-day topography that closely linked to the building of Tibet plateau and associated continental rivers systems, the evolving rift basins that largely controlled by the subduction of Pacific 
Plate (Xu et al., 2021; Zhu et al., 2019) also had been established a large river systemEAR, approximately over $1500 \mathrm{~km}$ long and covered a considerable part of the East Asia margin (Fig.6B). This finding filled the gap of the landscape evolving histories in East Asia between the basin-and-swell landscape of the early Cenozoic and the presentday landscape and showed how deep earth processes, caused by multiple stage subduction, control the reorganization of river networks of the earth surface.

\section{Conclusions}

The detrital zircon ages from the early Eocene sediments show identical feature with the Paleocene with one singe age peak at $\sim 110 \mathrm{Ma}$. This result together with previous detrital zircon ages clearly manifest the provenance changes that multiple age peaks (110 Ma, $230 \mathrm{Ma}, 800 \mathrm{Ma}, 1850 \mathrm{Ma}$ and $2500 \mathrm{Ma}$ ) in ECSB occurred at middle Eocene. The MDS plot shows close affinity with North China Block and Korea peninsular suggesting the source areas located far inland. The overwhelmingly fluvial sediments of the middle Eocene in Subei-South Yellow Sea Basin indicated that external river formed in this basin and a bypassing region of this basin. The Jianghan Basin and Bohai Basin were sedimentary-isolated basin or hydrologic-isolated basin. Thus, there had been a large river system initially established at the middle Eocene, which originated the Korea Peninsular and North China Block, flowed through the Subei-South Yellow Sea Basin, and drain into the southern ECSB. This river might last to the middle Miocene. The deep earth process of Izanagi-Pacific ridge subduction resulted in overfilled Subei-South Yellow Sea Basin and termination of rifting stage in west depression zone in ECSB, and thus, led to the formation of the EAR. This finding shed new light on landscape evolution of East Asia. 


\section{References}

Bohacs, K., Carroll, A., Neal, Neal, J., Mankiewicz, 2000. Lake-Basin Type, Source Potentional, and Hydrocarbon Character:An Integrated Sequence-Stratigraphic-Geochemichal Framework, pp. 3-33.

Brookfield, M.J.G., 1998. The evolution of the great river systems of southern Asia during the Cenozoic India-Asia collision: rivers draining southwards. 22, 285-312.

Caracciolo, L., 2020. Sediment generation and sediment routing systems from a quantitative provenance analysis perspective: Review, application and future development. Earth-Science Reviews 209, 103226. Cawood, P.A., Nemchin, A.A., Freeman, M., Sircombe, K.J.E., Letters, P.S., 2003. Linking source and sedimentary basin: Detrital zircon record of sediment flux along a modern river system and implications for provenance studies. Earth Planetary Science Letters 210, 259-268.

Chen, K., Gao, S., Wu, Y., Guo, J., Hu, Z., Liu, Y., Zong, K., Liang, Z., Geng, X., 2013. 2.6-2.7Ga crustal growth in Yangtze craton, South China. Precambrian Research 224, 472-490.

Chéry, J., Lucazeau, F., Daignières, M., Vilotte, J.P., 1992. Large uplift of rift flanks: A genetic link with lithospheric rigidity? Earth and Planetary Science Letters 112, 195-211.

Chew, D., O’Sullivan, G., Caracciolo, L., Mark, C., Tyrrell, S., 2020. Sourcing the sand: Accessory mineral fertility, analytical and other biases in detrital U-Pb provenance analysis. Earth-Science Reviews $202,103093$.

Choi, T., Lee, Y.I., Orihashi, Y.J.G.F., 2016. Crustal growth history of the Korean Peninsula: Constraints from detrital zircon ages in modern river sediments. Geoscience Frontiers 7, 707-714.

Chough, S.K., Kwon, S.T., Ree, J.H., Choi, D.K., 2000. Tectonic and sedimentary evolution of the Korean peninsula: a review and new view. Earth-Science Reviews 52, 175-235.

Clark, M.K., Schoenbohm, L.M., Royden, L.H., Whipple, K.X., Burchfiel, B.C., Zhang, X., Tang, W., Wang, E., Chen, L., 2004. Surface uplift, tectonics, and erosion of eastern Tibet from large-scale drainage patterns. Tectonics 23

Clift, P.D., Carter, A., Nicholson, U., Masago, H.J.T., 2013. Zircon and apatite thermochronology of the Nankai Trough accretionary prism and trench, Japan: Sediment transport in an active and collisional margin setting. Tectonics 32, 377-395.

Deng, K., Yang, S., Li, C., Su, N., Bi, L., Chang, Y.-P., Chang, S.-C.J.E.-S.R., 2017. Detrital zircon geochronology of river sands from Taiwan: Implications for sedimentary provenance of Taiwan and its source link with the east China mainland. Earth-Science Reviews 164, 31-47.

Einsele, G., Hinderer, M.J.G.R., 1997. Terrestrial sediment yield and the lifetimes of reservoirs, lakes, and larger basins. $86,288-310$.

Eynatten, H.v., Dunkl, I.J.E.-S.R., 2012. Assessing the sediment factory: The role of single grain analysis. 115, 97-120.

Faccenna, C., Becker, T., Lallemand, S., Steinberger, B., 2012. On the role of slab pull in the Cenozoic motion of the Pacific. Geophysical Research Letters 39, 3305.

Fedo, C.M., Sircombe, K.N., Rainbird, R.H., 2003. Detrital Zircon Analysis of the Sedimentary Record. Reviews in Mineralogy and Geochemistry 53, 277-303.

Frostick, L., Reid, I., 1989. Is structure the main control of river drainage and sedimentation in rifts? Journal of African Earth Sciences (and the Middle East) 8, 165-182.

Fu, X., Zhu, W., Geng, J., Yang, S., Zhong, K., Huang, X., Zhang, L., Xu, X.J.J.o.A.E.S., 2021. The present-day Yangtze River was established in the late Miocene: Evidence from detrital zircon ages. 205, 
104600.

Gawthorpe, R.L., Leeder, M.R., 2008. Tectono-sedimentary evolution of active extensional basins. 12 , 195-218.

Griffin, W.L., Belousova, E.A., Shee, S.R., Pearson, N.J., O’Reilly, S.Y., 2004. Archean crustal evolution in the northern Yilgarn Craton: $\mathrm{U}-\mathrm{Pb}$ and Hf-isotope evidence from detrital zircons. Precambrian Research 131, 231-282.

He, J., Garzanti, E., Cao, L., Wang, H., 2020. The zircon story of the Pearl River (China) from Cretaceous to present. Earth-Science Reviews 201, 103078.

He, M., Zheng, H., Bookhagen, B., Clift, P.D.J.E.-S.R., 2014. Controls on erosion intensity in the Yangtze River basin tracked by U-Pb detrital zircon dating. Earth-Science Reviews 136, 121-140.

Hietpas, J., Samson, S.D., Moecher, D.P., Chakraborty, S.J.J.o.t.G.S., 2011. Enhancing tectonic and provenance information from detrital zircon studies: assessing terrane-scale sampling and grain-scale characterization. $168,309-318$.

Huang, C., Zhang, J., Wang, H., Jiang, S., 2015. Lacustrine Shale Deposition and Variable Tectonic Accommodation in the Rift Basins of the Bohai Bay Basin in Eastern China. Journal of Earth Science 26, 700-711.

Kano, K., Uto, K., Ohguchi, T., 2007. Stratigraphic review of Eocene to Oligocene successions along the eastern Japan Sea: Implication for early opening of the Japan Sea. Journal of Asian Earth Sciences 30, 20-32.

Kwon, Y.-I., Boggs, S., 2002. Provenance interpretation of Tertiary sandstones from the Cheju Basin (NE East China Sea): a comparison of conventional petrographic and scanning cathodoluminescence techniques. Sedimentary Geology 152, 29-43.

Lee, G.H., Kim, B., Shin, K.S., Sunwoo, D., 2006. Geologic evolution and aspects of the petroleum geology of the northern East China Sea shelf basin. AAPG Bulletin 90, 237-260.

Li, J., Zhang, Y., Dong, S., Johnston, S.T., 2014a. Cretaceous tectonic evolution of South China: A preliminary synthesis. Earth-Science Reviews 134, 98-136.

Li, S., Jahn, B.-m., Zhao, S., Dai, L., Li, X., Suo, Y., Guo, L., Wang, Y., Liu, X., Lan, H.J.E.-S.R., 2017. Triassic southeastward subduction of North China Block to South China Block: Insights from new geological, geophysical and geochemical data. 166, 270-285.

Li, X.-H., Li, Z.-X., Li, W.-X.J.G.R., 2014b. Detrital zircon U-Pb age and Hf isotope constrains on the generation and reworking of Precambrian continental crust in the Cathaysia Block, South China: A synthesis. 25, 1202-1215.

Liu, C., Clift, P.D., Murray, R.W., Blusztajn, J., Ireland, T., Wan, S., Ding, W., 2017. Geochemical evidence for initiation of the modern Mekong delta in the southwestern South China Sea after 8Ma. Chemical Geology 451, 38-54.

Liu, J., Wang, L., XiaoLing, J., Du, M., Wang, G., 2015. Analyzing geochemical characteristics and hydrocarbon generation history of the Middle and Upper Jurassic source rocks in the North Yellow Sea Basin. Journal of Petroleum Science and Engineering 126, 141-151.

Metcalfe, I.J.G.R., 2006. Palaeozoic and Mesozoic tectonic evolution and palaeogeography of East Asian crustal fragments: the Korean Peninsula in context. 9, 24-46.

Müller, R.D., Sdrolias, M., Gaina, C., Steinberger, B., Heine, C., 2008. Long-Term Sea-Level Fluctuations Driven by Ocean Basin Dynamics. Science 319, 1357.

Paul, J.D., Roberts, G.G., White, N., 2014. The African landscape through space and time. 33, 898-935. Paul, J.D.J.G., 2021. Controls on eroded rock volume, a proxy for river incision, in Africa. 49, 422 - 
427.

Qi, J., Yang, Q., 2010. Cenozoic structural deformation and dynamic processes of the Bohai Bay basin province, China. Marine and Petroleum Geology 27, 757-771.

Ren, J., Tamaki, K., Li, S., Junxia, Z.J.T., 2002. Late Mesozoic and Cenozoic rifting and its dynamic setting in Eastern China and adjacent areas. Tectonophysics 344, 175-205.

Richardson, N.J., Densmore, A.L., Seward, D., Wipf, M., Yong, L., 2010. Did incision of the Three Gorges begin in the Eocene? Geology 38, 551-554.

Seton, M., Flament, N., Whittaker, J., Müller, R.D., Gurnis, M., Bower, D.J., 2015. Ridge subduction sparked reorganization of the Pacific plate-mantle system 60-50 million years ago. Geophysical Research Letters 42, 1732-1740.

Shao, L., Cao, L., Qiao, P., Zhang, X., Li, Q., van Hinsbergen, D.J.J., 2017. Cretaceous-Eocene provenance connections between the Palawan Continental Terrane and the northern South China Sea margin. Earth and Planetary Science Letters 477, 97-107.

Sláma, J., Košler, J., 2012. Effects of sampling and mineral separation on accuracy of detrital zircon studies. Geochemistry, Geophysics, Geosystems 13.

Song, Y., Hu, S., Xu, J., Shen, C., Li, S., Su, P., Xie, W., 2020. Lacustrine environmental evolution and implications on source rock deposition in the Upper Cretaceous-Paleocene of the South Yellow Sea Basin, offshore eastern China. Marine and Petroleum Geology 113, 104135.

Sun, X., Tian, Y., Kuiper, K.F., Li, C.a., Zhang, Z., Wijbrans, J.R., 2021. No Yangtze River Prior to the Late Miocene: Evidence From Detrital Muscovite and K-Feldspar 40Ar/39Ar Geochronology. Geophysical Research Letters 48, e2020GL089903.

Sundell, K.E., Saylor, J.E., 2017. Unmixing detrital geochronology age distributions. Geochemistry, Geophysics, Geosystems 18, 2872-2886.

Van Horne, A., Sato, H., Ishiyama, T., 2017. Evolution of the Sea of Japan back-arc and some unsolved issues. Tectonophysics 710-711, 6-20.

Vermeesch, P., Resentini, A., Garzanti, E.J.S.G., 2016. An R package for statistical provenance analysis. Sedimentary Geology 336, 14-25.

Wang, L.-J., Griffin, W.L., Yu, J.-H., O’Reilly, S.Y., 2010. Precambrian crustal evolution of the Yangtze Block tracked by detrital zircons from Neoproterozoic sedimentary rocks. Precambrian Research 177, 131-144.

Wang, P., 2004. Cenozoic Deformation and History of Sea-Land Interaction in Asia.

Wang, R., Shi, W., Xie, X., Wang, L., Manger, W., Busbey, A.B., Xu, Q., 2017. Lower Cretaceous lacustrine successions, North Yellow Sea Basin, eastern China: Rift basin sequence stratigraphy and stacking patterns in response to magmatic activity. Marine and Petroleum Geology 88, 531-550.

Wang, R., Shi, W., Xie, X., Zhang, X., Wang, L., Manger, W., Busbey, A.B., 2020. Coupling of strikeslip faulting and lacustrine basin evolution: sequence stratigraphy, structure, and sedimentation in the North Yellow Sea Basin (West Bay Basin offshore North Korea), eastern China. Marine and Petroleum Geology 120, 104548.

Wang, W., Bidgoli, T., Yang, X., Ye, J., 2018. Source-To-Sink Links Between East Asia and Taiwan From Detrital Zircon Geochronology of the Oligocene Huagang Formation in the East China Sea Shelf Basin. Geochemistry, Geophysics, Geosystems 19, 3673-3688.

Weissel, J.K., Karner, G.D., 1989. Flexural uplift of rift flanks due to mechanical unloading of the lithosphere during extension. Journal of Geophysical Research: Solid Earth 94, 13919-13950.

Wu, F.-Y., Yang, J.-H., Wilde, S.A., Liu, X.-M., Guo, J.-H., Zhai, M.-G.J.P.R., 2007. Detrital zircon U- 
$\mathrm{Pb}$ and $\mathrm{Hf}$ isotopic constraints on the crustal evolution of North Korea. 159, 155-177.

Wu, J.T.-J., Wu, J., 2019. Izanagi-Pacific ridge subduction revealed by a 56 to 46 Ma magmatic gap along the northeast Asian margin. Geology 47, 953-957.

Wu, L., Mei, L., Liu, Y., Luo, J., Min, C., Lu, S., Li, M., Guo, L., 2017. Multiple provenance of rift sediments in the composite basin-mountain system: Constraints from detrital zircon $\mathrm{U}-\mathrm{Pb}$ geochronology and heavy minerals of the early Eocene Jianghan Basin, central China. Sedimentary Geology 349, 4661.

Wu, Y.-B., Zheng, Y.-F., 2013. Tectonic evolution of a composite collision orogen: An overview on the Qinling-Tongbai-Hong'an-Dabie-Sulu orogenic belt in central China. Gondwana Research 23, 1402 1428 .

Xu, J., Ben-Avraham, Z., Kelty, T., Yu, H.-S., 2014a. Origin of marginal basins of the NW Pacific and their plate tectonic reconstructions. Earth-Science Reviews 130, 154-196.

Xu, J., Ben-Avraham, Z., Kelty, T., Yu, H.-S.J.E.-S.R., 2014b. Origin of marginal basins of the NW Pacific and their plate tectonic reconstructions. 130, 154-196.

Xu, X., O’Reilly, S.Y., Griffin, W.L., Wang, X., Pearson, N., He, Z.J.P.R., 2007. The crust of Cathaysia: age, assembly and reworking of two terranes. Precambrian Research 158, 51-78.

Xu, X., Zuza, A., Chen, L., Zhu, W., Yin, A., Fu, X., Gao, S., Xu, X., Kuang, X., Zhang, F., Wu, L., Lin, X., Chen, H., Yang, S., 2021. Late Cretaceous to Early Cenozoic extension in the Lower Yangtze region (East China) driven by Izanagi-Pacific plate subduction. Earth-Science Reviews.

Xu, Y., Wang, C.Y., Zhao, T.J.J.o.A.E.S., 2016. Using detrital zircons from river sands to constrain major tectono-thermal events of the Cathaysia Block, SE China. Journal of Asian Earth Sciences 124, 1-13.

Yao, J., Cawood, P.A., Shu, L., Zhao, G., 2019. Jiangnan Orogen, South China: A 970-820 Ma Rodinia margin accretionary belt. Earth-Science Reviews 196, 102872.

Yi, S., Yi, S., Batten, D.J., Yun, H., Park, S.-J., 2003. Cretaceous and Cenozoic non-marine deposits of the Northern South Yellow Sea Basin, offshore western Korea: palynostratigraphy and palaeoenvironments. Palaeogeography, Palaeoclimatology, Palaeoecology 191, 15-44.

Zhang, J., Krijgsman, W., Lu, Y., Liu, J., Li, X., Du, X., Wei, W., Lin, H., 2021a. Detrital zircon ages reveal Yangtze provenance since the early Oligocene in the East China Sea Shelf Basin. Palaeogeography, Palaeoclimatology, Palaeoecology 577, 110548.

Zhang, J., Lu, Y., Krijgsman, W., Liu, J., Li, X., Du, X., Wang, C., Liu, X., Feng, L., Wei, W., Lin, H., 2018. Source to sink transport in the Oligocene Huagang Formation of the Xihu Depression, East China Sea Shelf Basin. Marine and Petroleum Geology 98, 733-745.

Zhang, X., Dalrymple, R.W., Yang, S.-Y., Lin, C.-M., Wang, P.J.M.G., 2015. Provenance of Holocene sediments in the outer part of the Paleo-Qiantang River estuary, China. Marine Geology 366, 1-15.

Zhang, Z., Daly, J.S., Tyrrell, S., Sun, X., Badenszki, E., Li, Y., Zhang, D., Tian, Y., Yan, Y.J.E.-S.R., 2021b. Formation of the Three Gorges (Yangtze River) no earlier than 10 Ma. 103601.

Zheng, H., Clift, P., He, M., Bian, Z., Liu, G., Liu, X., Xia, L., Yang, Q., Jourdan, F., 2020. Formation of the First Bend in the late Eocene gave birth to the modern Yangtze River, China. Geology 49.

Zheng, H., Clift, P.D., Wang, P., Tada, R., Jia, J., He, M., Jourdan, F.J.P.o.t.N.A.o.S., 2013. Pre-Miocene birth of the Yangtze River. Proceedings of the National Academy of Sciences, 201216241.

Zheng, H., Jia, D., Chen, J., Wang, P.J.G., 2011. Did incision of the Three Gorges begin in the Eocene? COMMENT. Geology 39, e244-e244.

Zheng, H.J.N.S.R., 2015. Birth of the Yangtze River: age and tectonic-geomorphic implications. National Science Review 2, 438-453. 
Zhu, W., Kai, Z., Xiaowei, F., Chunfeng, C., Minqiang, Z., Shunli, G., 2019. The formation and evolution of the East China Sea Shelf Basin: A new view. Earth-Science Reviews 190, 89-111.

Zhu, X., Shen, C., Zhou, R., Xu, J., Zhao, J.-X., Wang, L., Ge, X., 2020. Paleogene sediment provenance and paleogeographic reconstruction of the South Yellow Sea Basin, East China: Constraints from detrital zircon $\mathrm{UPb}$ geochronology and heavy mineral assemblages. Palaeogeography, Palaeoclimatology, Palaeoecology 553, 109776.
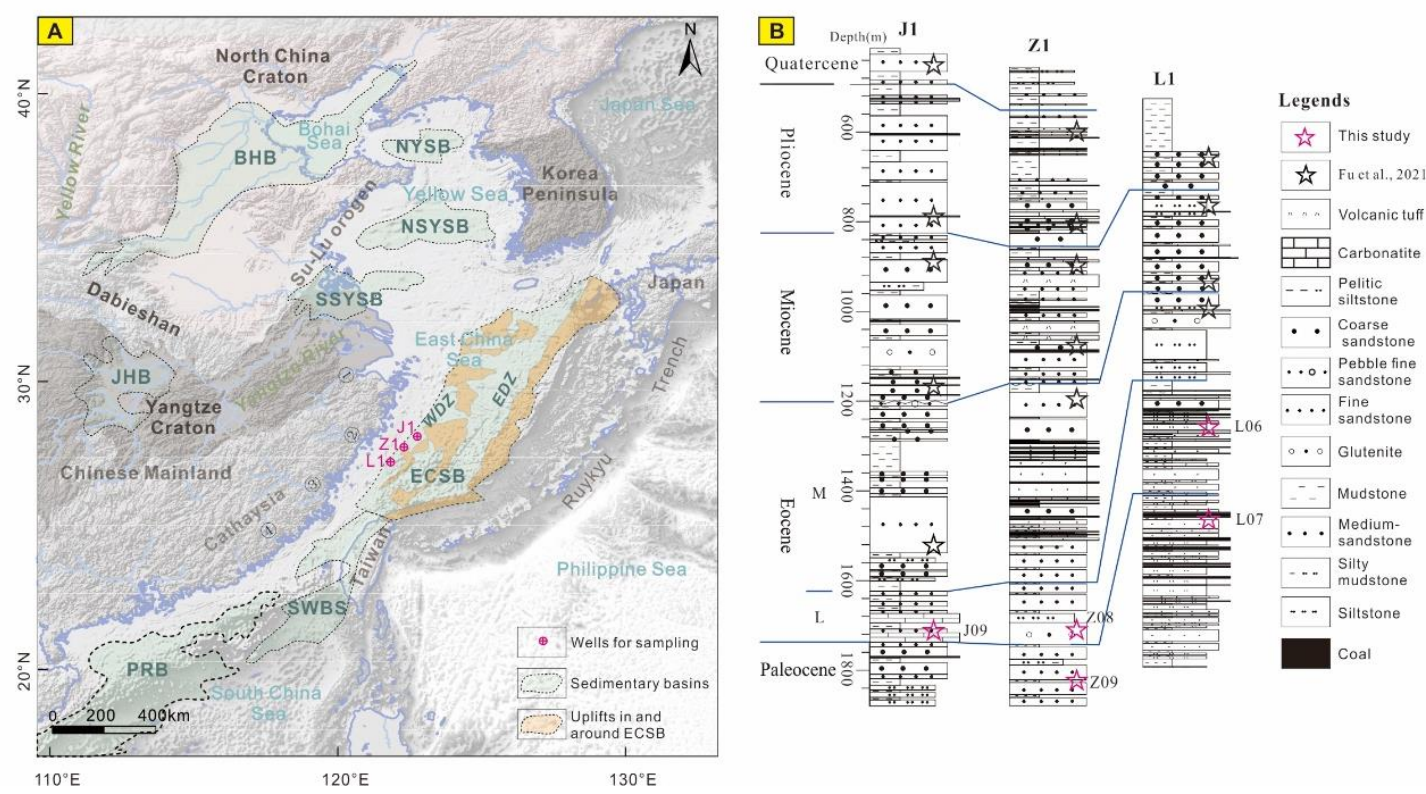

Fig. 1 A: Topographic map of East Asia, showing major basins and rivers related to potential sources. B: Sampling details for detrital zircons selected from industrial boreholes (modified from Fu et al., 2021). Tectonic sketch of the East China Sea Basin are modified from Zhu et al. (2019). Distribution of terranes are modified from Zhao et al. (2005) and Wissink and Hoke (2016); The basins on East Asia margin are modified from Ren et al. (2002); YB, Yinggehai Basin; PRB, Pearl River Mouth Basin; SWTB, Southwest Taiwan Basin; ECSB, East China Sea Basin; NSYSB, Northern Subei-South Yellow Sea Basin; SSYSB, Southern Subei-South Yellow Sea Basin; NYSB, Northern Yellow Sea Basin; JHB, Jianghan Basin; BHB, Bohai Basin; (1),Qiantang River; (2),Ou River; (3),Min River; (4),Jiulong River. 


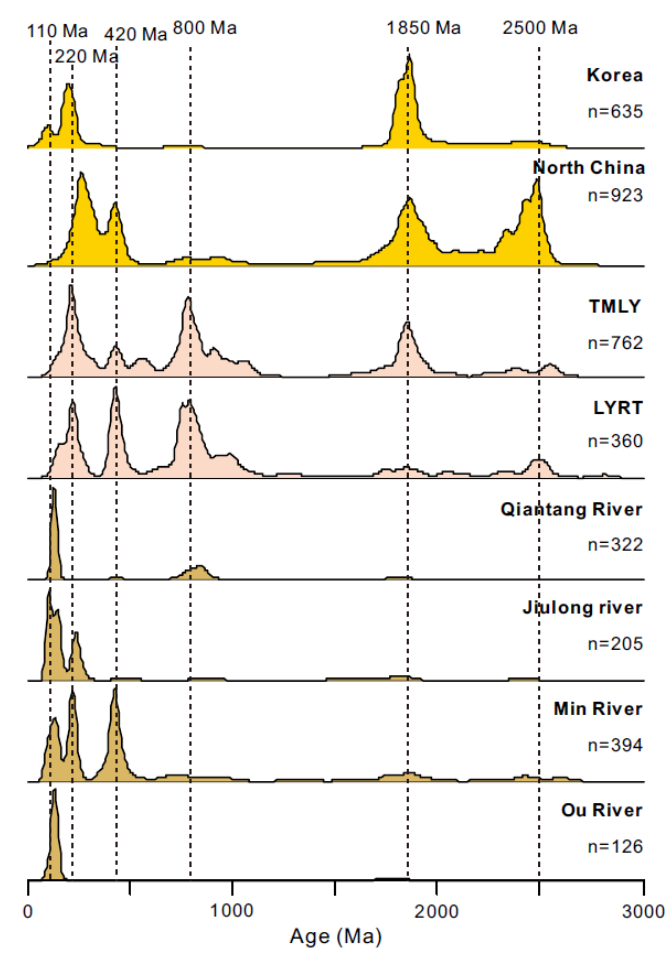

Fig.2 Provenance features of potential source areas. See Supplementary Table 1 for the data source. MLYR, trunk stream in middle and lower reaches of the Yangtze River; TMYR, tributaries in middle Yangtze River, which were used to represent the provenance feature of palaeo-Yangtze River. 


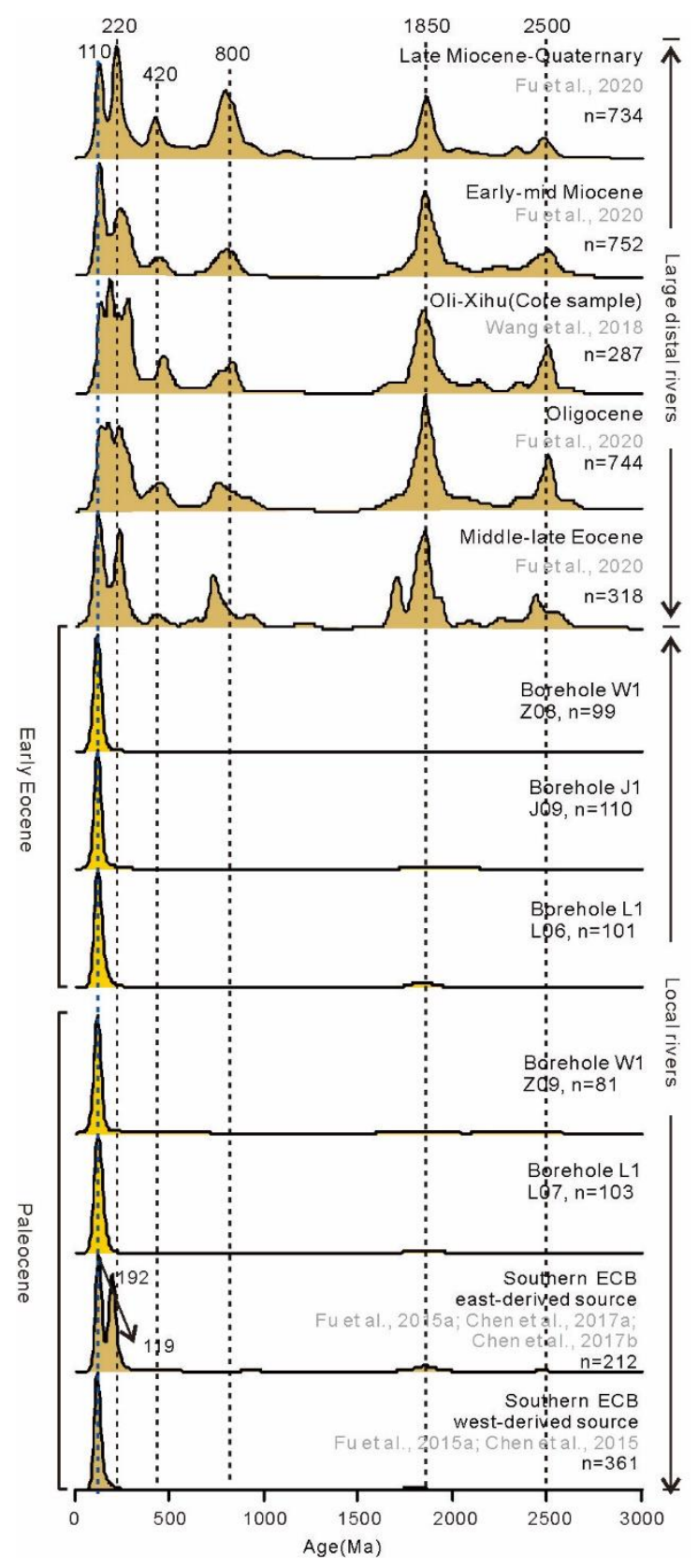

Fig. 3 Spectra of detrital zircon ages for Cenozoic sediments from the ECSB 

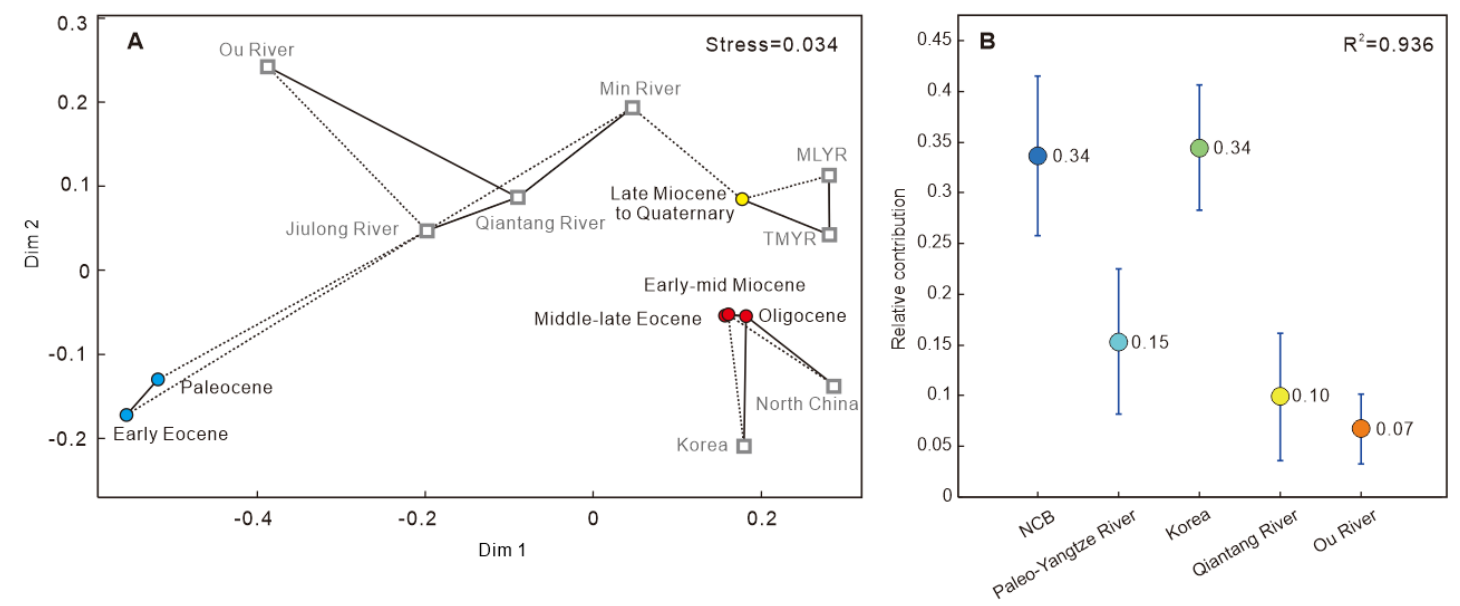

Fig. 4 A: Nonmetric multidimensional scaling (MDS; Vermeesch et al., 2016) maps of compiled detrital zircon $\mathrm{U}-\mathrm{Pb}$ ages from offshore basins in East China. B: Contributions of different sources through inverse Monte Carlo modelling based on Cross-correlation coefficient (R2) (Sundell and Saylor, 2017).

MLYR, middle and lower reaches of the Yangtze River trunk stream; TMYR, tributaries in the middle reaches of the Yangtze River. 


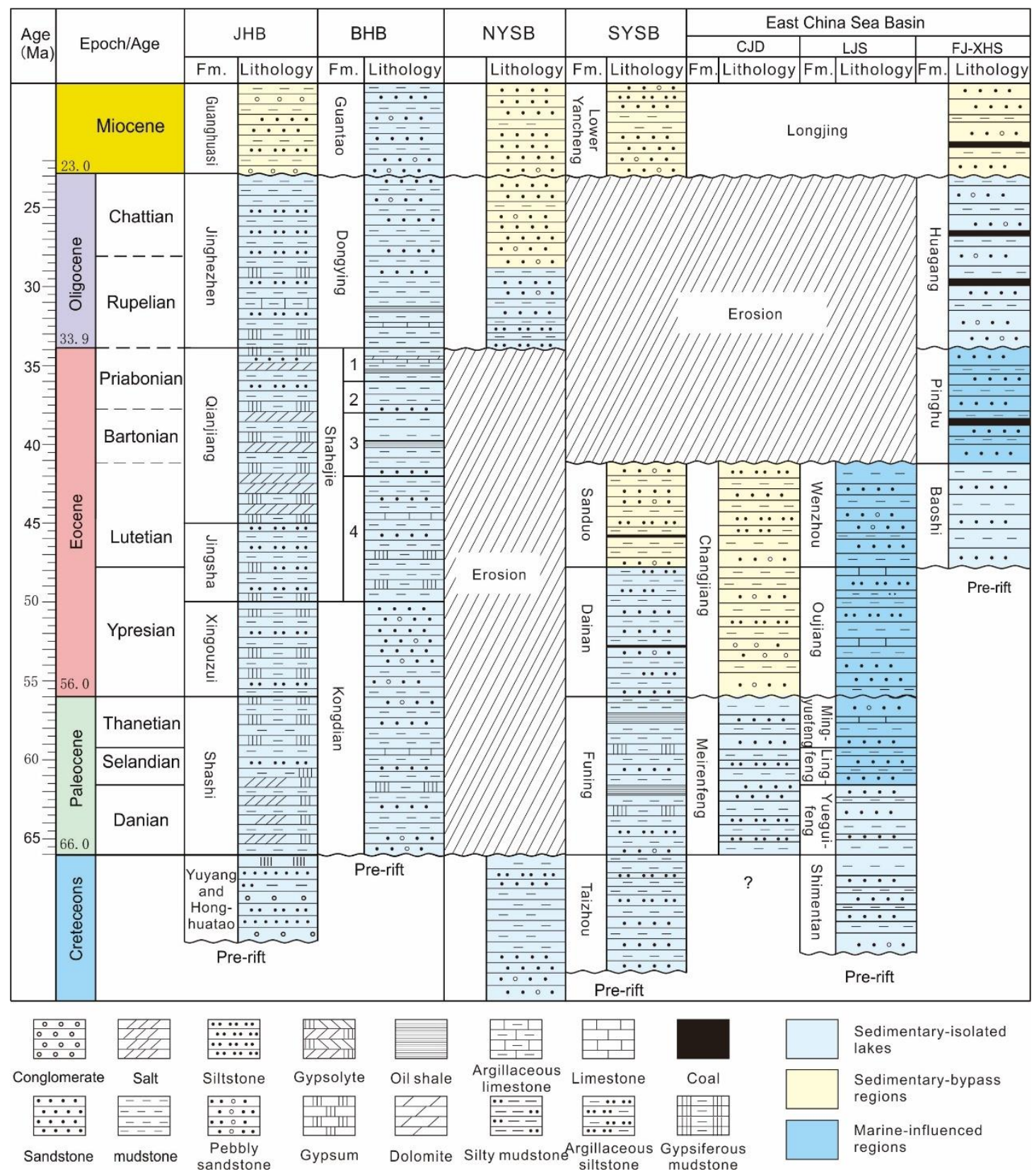

Fig. 5 Basin evolution and the potential effects on the lower reaches of river networks on East Asia margin. The lithology of the Jianghan Basin was modified from Wu et al. (2017), Zheng et al. (2011) and Dai et al. (1987); the lithology of the Subei-South Yellow Sea Basin was modified from Wang et al. (1985) and Zhu et al. (2009); the lithology of the North Yellow Sea Basin was modified from Wang et al. (2017); and the lithology of the East China Sea Basin was modified from Zhu et al. (2019). 

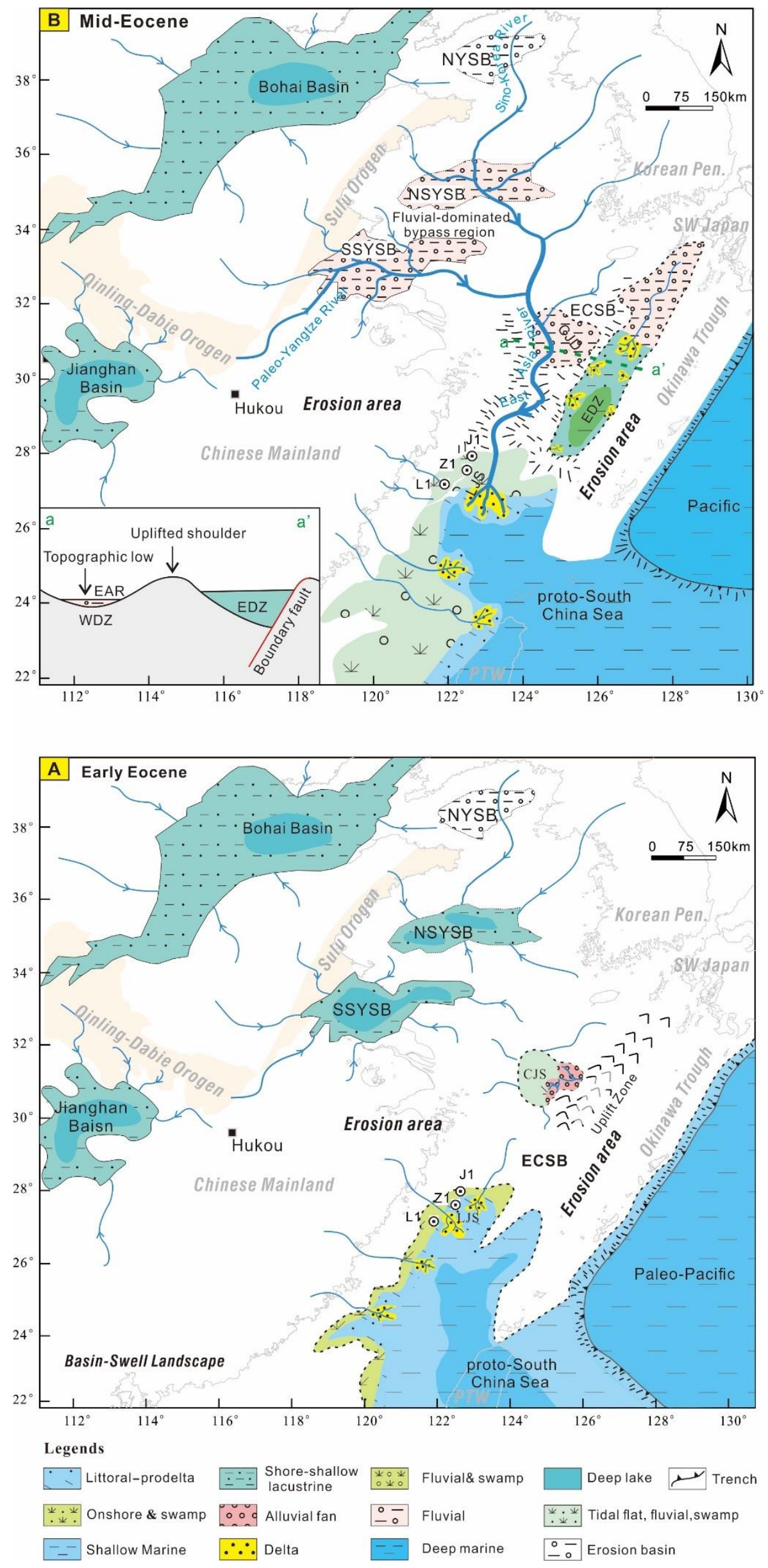
Fig.6 Schematic mode for the formation of EAR. The sedimentary palaeogeography in and around the ECB was modified from Zhu et al. (2019). LJS, Lishui-Jiaojiang Sag; CJS, Changjiang Sag; ECSB, East China Sea Basin; NYSB, North Yellow Sea Basin; SSYSB, southern Subei-South Yellow Sea Basin; NSYSB, Northern Subei-South Yellow Sea Basin; EDZ, East depression zone; WDZ, West depression zone. 